\title{
Dental caries' experience, prevalence and severity in Mexican adolescents and young adults
}

\section{Experiencia, prevalencia y severidad de caries dental en adolescentes y adultos jóvenes mexicanos}

José O. García-Cortés, ${ }^{1,2}$ Carlo E. Medina-Solís, ${ }^{3}$ Juan P. Loyola-Rodriguez, ${ }^{1}$ Jorge A. Mejía-Cruz, ${ }^{2}$ Eduardo Medina-Cerda, ${ }^{2}$ Nuria Patiño-Marín ${ }^{1}$ and América P. Pontigo-Loyola ${ }^{3}$

\footnotetext{
1 Facultad de Estomatología, Universidad Autónoma de San Luis Potosí, San Luis Potosí, México 2 Centro de Salud Universitario de la Universidad Autónoma de San Luis Potosí, San Luis Potosí, México

3 Área Académica de Odontología del Instituto de Ciencias de la Salud de la Universidad Autónoma del Estado de Hidalgo, Pachuca, Hidalgo, México. cemedinas@yahoo.com
}

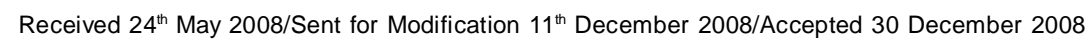

\section{ABSTRACT}

Objective Determining dental caries' experience, prevalence and severity in students applying for degree courses at San Luis Potosi University (UASLP).

Material and Methods A cross-sectional study was carried out involving adolescents and young adults (16 to 25 years old) applying for undergraduate courses at UASLP ( 10 $\%, \mathrm{n}=1$ 027). Two standardized examiners undertook dental examinations; DMFT index, prevalence (DMFT $>0$ ), severity (DMFT $>3$ and DMFT $>6$ ) and significant caries index (SiC) were calculated. STATA 9.0 non-parametric tests were used for statistical analysis.

Results Mean age was $18.20 \pm 1.65 ; 48.0 \%$ were female. The DMFT index was $4.04 \pm 3.90$ and caries prevalence was $74.4 \%$. Regarding caries' severity, $48.8 \%$ had MDFT $>3$ and $24 \%$ DMFT $>6$. The SiC index was 8.64. Females had higher caries experience than males $(4.32 \pm 4.01$ cf $3.78 \pm 3.78 ; p<0.05)$, but similar prevalence and severity $(p>0.05)$. Age was associated with both experience $(p<0.001)$ and prevalence $(p<0.01)$ and to differing degrees of caries' severity $(p<0,001)$. The «filled teeth» component had the highest DMFT index percentage (63.6\%) and «missing teeth» the lowest (11.4\%).

Conclusions High dental caries' experience, prevalence and severity were observed in this sample of adolescents and young adults. Restorative experience was high (59.5\%) compared to studies carried out in other parts of Mexico and Latin-America.

Key Words: Oral health, dental caries, adolescent health, Mexico (source: MeSH, NLM).

\section{RESUMEN}

Objetivo Determinar la experiencia, prevalencia y severidad de caries en aspirantes a las licenciaturas de la Universidad Autónoma de San Luis Potosí (UASLP).

Material y Métodos Se realizó un estudio transversal descriptivo en el 2007 en una 
muestra de adolescentes y adultos jóvenes de 16 a 25 años de edad aspirantes a las licenciaturas de la UASLP ( 10\%, $\mathrm{n}=1$ 027). El examen clínico lo realizaron dentistas. Se calcularon los índices de caries para dentición permanente y se determinó la experiencia (índice global CPOD), la prevalencia (CPOD>0) y la severidad (CPOD>3 y CPOD $>6$ ) de caries dental, además, del índice de caries significativa ( $\mathrm{SiC}$ ). Los análisis estadísticos se realizaron con $\mathrm{X}^{2}$, Mann-Whitney, y pruebas de tendencia no paramétrica en STATA 9.0.

Resultados La edad promedio fue 18,20 $\pm 1,65$ años. El 48,0 \% fueron mujeres. El índice CPOD fue 4,04 $\pm 3,90$ y la prevalencia de caries de $74,4 \%$. En cuanto a la severidad, $48,8 \%$ tuvieron CPOD >3 y 24,0 \% CPOD >6. El índice $\mathrm{SiC}$ fue de 8,64. Las mujeres tuvieron mayor experiencia de caries que los hombres $(4,32 \pm 4,01$ vs $3,78 \pm 3,78 ; p<0,05)$; pero similar prevalencia y severidad $(p>0,05)$. La edad se asoció tanto a la experiencia $(p<0,001)$, como a la prevalencia $(p<0,01)$ y a los diferentes grados de severidad de caries $(p<0,001)$. El mayor porcentaje $(63,6 \%)$ del índice CPOD fue del componente «dientes obturados» y el menor $(11,4 \%)$ del componente "dientes perdidos".

Conclusiones Se observó una alta experiencia, prevalencia y severidad de caries en esta muestra de adolescentes y adultos jóvenes. Por otro lado, la experiencia restauradora fue alta $(59,5 \%)$ en comparación con estudios realizados en otros lugares de México y Latinoamérica.

Palabras Clave: Salud bucal, caries dental, salud del adolescente, México (fuente: DeCS, BIREME).

$\mathrm{D}$ ental caries is a public oral health problem and one of the major unmet needs in oral health amongst the teenage population of Mexico and other Latin-American countries (1-6). It is an infectious-contagious disease implying an imbalance of normal molecular interactions between the teeth's surface/subsurface and the adjacent microbial biofilm. It becomes expressed during a certain period of time as an accumulative demineralization which, if not treated, has the potential for producing cavities in the enamel and collateral damage in dentine and pulpar tissues (7). Dental caries still remains a dental health problem in several countries; several studies have been carried out in Mexico during the last two decades in different age-groups. A $48 \%$ to $95 \%$ prevalence was reported in preschool children (8-13) while $42 \%$ to $88 \%$ dental caries prevalence was reported in a group of 12-year-old children $(6,14-16)$ and $53.4 \%$ prevalence in a 15 -year-old group of adolescents (6). Dental caries has thus been mainly studied in groups of children and adolescents aged 3 to 15 . However, adolescents older than 15 and adults younger than 26 are frequently not included in oral health reports.

Most epidemiological studies on dental caries affecting such age-groups have been carried out in high-income countries; a group of researchers observed 
that $92 \%$ of 18-year-old adolescents in New Zealand presented dental caries (15). Italian researchers reported $87.8 \%$ caries prevalence in 18-year-old adolescents; the DMFT index was 6.18 (16) whereas the DMFT index was reported to be 6.77 in 18-year-old adolescents in Israel (17). Hopcraft and Morgan (18) carried out a study in Australia where a 3.59 DMFT index was reported for 17-20-year-old conscripts and 4.63 DMFT index for 21 to 25year-old young adults. DMFT indexes in a subsequent study were reported to be 2.43 and 3.44 and $67.2 \%$ and $73.5 \%$ caries prevalence for the same agegroups, respectively (19).

Regarding Latin-American countries, several studies have been made in Brazil about adolescents and young adults; however, most of them have been carried out on males (mainly army conscripts) in which the mean for affected teeth was 4.5-4.6 and prevalence reported was 81-82.6 \% (20,21). Gushi et al., (3) have reported a 7.09 DMFT index in 16 to 19-year-old boys; however, in a study performed on dentistry students in Mexico City it was observed that the DMFT index was 3 to 3.5 in 17 to 24 -year-old groups (22).

Lack of epidemiological information concerning this population group's oral health is a serious limitation as it is important to ascertain the disease's behaviour in all age-groups (as this allows epidemiological monitoring) and the possibility of expanding oral health services to other age-groups including adolescents and young adults increases reduction of caries' prevalence and severity in preschool children (20). This study was thus aimed at determining dental caries' experience, prevalence and severity in a sample of adolescents and young adults applying to San Luis Potosi University during 2007 as there is limited oral health information concerning adolescents in Mexico.

\section{MATERIALS AND METHODS}

Design, population and sample of study

San Luis Potosi (SLP) is located in north-central Mexico; it covers $62,849 \mathrm{~km}^{2}$ and has a population of 2,410,414. The total population having access to public health services is only $51.3 \%$. The state marginalization index (SMI) is 0.65573 , putting it amongst those states catalogued as having high marginalisation and also meaning that it has high social-spatial inequity (23). The economy is mainly based on the manufacturing industry, trade and non-financial services and construction (24). SLP state participates in the National Salt Fluoridation Programme; according to the Mexican Salt Association there are two types of 
salt which are distributed throughout the state: iodized and iodized/fluorated (25). SLP state has 58 municipalities; iodized/fluorated salt must not be ingested in 21 of them (26).

This cross-sectional study involved $10 \%$ of the total student population ( $\mathrm{N}=10$ 160 ) including adolescents and young adults (16 to 25 -year-old) from January $15^{\text {th }}$ to June $25^{\text {th }} 2007$. The subjects were randomly selected from the total number of applicants for the Universidad Autonoma de San Luis Potosi University's (UASLP) bachelor's degree programme. This is the public state university and concentrates most university students from all social-economic levels.

The inclusion criteria were as follows: students from either gender aged 16 to 25 applying to any course at UASLP. The exclusion criteria were: applicants for any course at UASLP who did not arrive at their oral examination appointment for ascertaining the presence of orthodontic appliances. The final sample thus consisted of 1,027 of the initially included 1,050 subjects who fulfilled the selection criteria.

Variables and data collecting

Informed and voluntary written-consent was obtained prior to clinical examination, according to the Declaration of Helsinki's ethical guidelines (27). The protocol was approved by the Clinical Research Committee for the Master's Degree in Dental Science with Specialisation in Advanced General Dentistry Programme at UASLP, Mexico. Eight dentists from the UASLP University Health Unit undertook subject recruitment, each dental examination being performed in artificial light using a dental mirror and explorer. The WHO caries' diagnostic criteria were used for determining the permanent tooth DMFT index (decayed, missing and filled tooth surfaces) (28). The outcome variables in the study were: having had caries (meaning DMFT index overall average), caries' prevalence in permanent dentition (rated $0=$ if DMFT was zero and $1=$ if DMFT was higher than zero), high caries' experience in permanent dentition (rated $0=$ if $\angle 4$ DMFT and $1=$ if $\mathrm{e}^{3} 4 \mathrm{DMFT}$ ) and very high experience of caries in permanent dentition (rated $0=$ if $<7$ DMFT and $1=$ if $\mathrm{e}^{3} 7 \mathrm{DMFT}$ ). The significant caries index (SiC) was also calculated; this refers to the DMFT for the third of the population which is most affected by caries (29). The subjects' age and gender represented the study's independent variables. The care index (CI) was also calculated as part of the analysis as this shows the restorative care to which a population has been exposed $(30,31)$ : 


$$
C I=\frac{\text { filling teeth }}{D M F T}(\mathbf{1 0 0 )}
$$

The treatment needs index (TNI) was calculated using the following formula:

$$
T N I=\frac{\text { teeth with caries }}{\text { teeth with caries }+ \text { filling teeth }}(100)
$$

Statistical analysis

Two examiners were trained and standardized using a Kappa test $(>0.90)$ before starting the study. All data were expressed as mean \pm standard deviation for continuous variables; frequencies and percentages were calculated for categorical data. Shapiro-Wilks, Levene and Brown Forsythe tests were used for testing variable distribution. The non-parametric Mann-Whitney test was used for comparing continuous variables and the $\mathrm{X}^{2}$ test for comparing categorical variables. STATA version 9.0 was used for statistical analysis; statistical significance was set at $\mathrm{p}<0.05$.

\section{RESULTS}

The study involved 1,027 individuals; $852(83.0 \%)$ were adolescents and $175(17.0 \%)$ young adults, mean age was $18.20 \pm 1.65$ and $48.0 \%$ were female. Tables 1a and $1 \mathrm{~b}$ show the DMFT index and the distribution of its components. The DMFT global index was 4.04 \pm 3.90 . Table 2 shows the results for caries' prevalence and severity. Caries' prevalence was $74.4 \%$; regarding severity, $48.8 \%$ had $>3 \mathrm{CPOD}$ and $24.0 \%>6 \mathrm{CPOD}$. The $\mathrm{SiC}$ index was 8.64 and TNI was $28.2 \%$.

It was observed in the bivariate analysis (Tables 1 and 2) that females had a higher experience of caries than males $(4.32 \pm 4.01$ of $3.78 \pm 3.78 ; \mathrm{p}=0.0350)$ but similar prevalence and severity $(\mathrm{p}>0.05)$. There was no statistical difference between females and males for the missing teeth $(0.40 \pm 1.06$ cf $0.52 \pm 1.19$; $\mathrm{p}=0.0622)$ and filled teeth $(2.38 \pm 3.47 c f 2.78 \pm 3.71 ; \mathrm{p}=0.0678)$. It was observed in the non-parametrical test that when age increased so did DMFT in both the male $(p<0.01)$ and female groups $(p<0.001)$. The DMFT index component having the highest percentage $(63.6 \%)$ was filled teeth (or CI) and missing teeth the lowest $(11.4 \%)$. Age was associated with both prevalence $(\mathrm{p}<0.01)$ and caries severity $(\mathrm{p}<0.001)$. 
Table 1. Distribution of DMFT index components by age and gender in the sample of adolescents and young adults included in the study

\begin{tabular}{|c|c|c|c|c|c|c|c|c|c|}
\hline \multirow{2}{*}{ Age $(n)$} & \multirow{2}{*}{$\begin{array}{c}\text { DMFT (SD) } \\
\text { All * }^{*}\end{array}$} & \multicolumn{2}{|c|}{ DMFT (SD) } & \multicolumn{2}{|c|}{$\mathrm{TC}\langle\mathrm{SD})$} & \multicolumn{2}{|c|}{$M T(S D)$} & \multicolumn{2}{|c|}{$\mathrm{FT}(\mathrm{SD})$} \\
\hline & & $\mathrm{M} t$ & $W \ddagger$ & $\mathrm{M \pi}$ & WI & MI & W§ & $M \ddagger$ & $w \ddagger$ \\
\hline $16(113)$ & $3.47(3.61)$ & $3.00(3.62)$ & $3.88(3.58)$ & $1.08(1.85)$ & $1.65(2.03)$ & $0.32(1.03)$ & $0.50(1.13)$ & $1.60(3.05)$ & $1.73(3.16)$ \\
\hline $17(253)$ & $3.60(3.84)$ & $3.71(3.97)$ & $3.51(3.73)$ & $1.33(2.20)$ & $0.96(1.90)$ & $0.40(1.06)$ & $0.44\langle 1.12\}$ & $1.98(3.43)$ & $2.11(3.18)$ \\
\hline $18(340)$ & $3.95(3.91)$ & $3.48(3.60)$ & $4.40(4.16)$ & $1.04(1.88)$ & $0.95(1.97)$ & $0.42(1.11)$ & $0.53(1.24)$ & $2.02(3.19)$ & $2.92(3.87)$ \\
\hline $19(146)$ & $4.04(3.62)$ & $3.74(3.52)$ & $4.38(3.72)$ & $0.70\langle 1.30\rangle$ & $0.87(1.47)$ & $0.27(0.93)$ & $0.57(1.29)$ & $2.77(3.55)$ & $2.94\langle 3.49\}$ \\
\hline $20(77)$ & $5.00(3.92)$ & $4.96(4.13)$ & $5.09(3.48)$ & $0.89\langle 1.64\rangle$ & $0.78(1.35)$ & $0.46(1.02)$ & $0.43(1.04)$ & $3.61(3.80)$ & $3.87\langle 3.77\rangle$ \\
\hline $21(47)$ & $4.98(4.52)$ & $3.8(3.95)$ & $7.06(4.81)$ & $0.67(1.15)$ & $0.65(1.17)$ & $0.47(1.17)$ & $0.76(0.83)$ & $2.67(3.79)$ & $5.65(4.90)$ \\
\hline $\begin{array}{l}22-25 \\
\text { (51) }\end{array}$ & $5.76(4.16)$ & $4.89(3.74)$ & $7.87(4.49)$ & $0.89\langle 1.62\rangle$ & $1.13(2.13)$ & $0.50(1.11)$ & $0.87(1.64)$ & $3.50(3.81)$ & $5.87(4.45)$ \\
\hline \multirow[t]{2}{*}{ Subtotal } & & $3.78(3.78)$ & $4.32(4.01)$ & \multirow{2}{*}{\multicolumn{2}{|c|}{$\begin{array}{l}1.01(1.82) \quad 1.01(1.86) \\
\text { Mann-Whitney } p=0.8477\end{array}$}} & \multirow{2}{*}{\multicolumn{2}{|c|}{ Mann-Whitney $p=00622$}} & \multirow{2}{*}{\multicolumn{2}{|c|}{ Mann -Whitney $\mathrm{p}=0.0678$}} \\
\hline & & \multicolumn{2}{|c|}{ Mann-Whitney $p=0.0350$} & & & & & & \\
\hline $\begin{array}{c}\text { Total } \\
(\mathrm{n}=1 \\
027)\end{array}$ & $404(390)$ & \multicolumn{2}{|c|}{$4.04(3.90)$} & \multicolumn{2}{|c|}{$1.01(1.83)$} & \multicolumn{2}{|c|}{$0.46(1.13)$} & \multicolumn{2}{|c|}{$2.57(3.59)$} \\
\hline
\end{tabular}

*Non-parametric test for DMFT index tendency by age, $z=4.75, p<0.001$. Non-parametric test for tendency by gender: $\uparrow p<0.01, \ddagger p<0.001$, I non-significant, $\$ p<0.10$. DMFT=average of teeth with caries, missing teeth and filled teeth; $(\mathrm{SD})=$ standard deviation; $\mathrm{TC}=$ average of teeth with caries; $\mathrm{MT}=$ average of missing teeth, $\mathrm{FT}=$ average of filled teeth. $\mathrm{M}=$ males; $\mathrm{W}$ =females

Table 3 shows the results for dental caries prevalence by age and gender. It was found that young adults had a higher risk of dental caries (2.21 RM; $1.42-3.4495 \% \mathrm{CI}$ ) than adolescents; females had $28 \%$ more possibility of having caries than males $(\mathrm{p}<0.10)$.

Table 2. Distribution of caries prevalence and severity by age and gender in the sample of adolescents and young adults included in the study

\begin{tabular}{|c|c|c|c|c|c|c|c|c|}
\hline \multirow{2}{*}{$\operatorname{Age}(n)$} & \multirow{2}{*}{$\begin{array}{c}\% \text { DMFT }=0 \\
\text { All }^{*}\end{array}$} & \multicolumn{2}{|c|}{$\%$ DMFT $=0$} & \multicolumn{2}{|c|}{$\%>3$ DMFT } & \multicolumn{2}{|c|}{$\%>6$ DMFT } & \multirow[t]{2}{*}{$\mathrm{SiC}$} \\
\hline & & $\mathrm{M} \dagger$ & WA & $\mathrm{M} \pm$ & W† & $\mathrm{M} \dagger$ & WI & \\
\hline $16(113)$ & 69.9 & 58.5 & 80.0 & 35.9 & 48.3 & 13.2 & 21.7 & 7.69 \\
\hline $17(253)$ & 70.8 & 71.2 & 70.4 & 42.4 & 44.4 & 24.6 & 15.6 & 8.13 \\
\hline $18(340)$ & 72.9 & 71.7 & 74.1 & 43.4 & 51.7 & 18.7 & 27.0 & 8.57 \\
\hline $19(146)$ & 75.3 & 74.0 & 76.8 & 50.7 & 56.5 & 22.1 & 27.5 & 8.18 \\
\hline $20(77)$ & 81.8 & 79.6 & 87.0 & 59.3 & 65.2 & 33.3 & 26.1 & 9.38 \\
\hline $21(47)$ & 87.2 & 83.3 & 94.1 & 40.0 & 64.7 & 20.0 & 52.9 & 10.25 \\
\hline $22-25(51)$ & 86.3 & 83.3 & 93.1 & 58.3 & 80.0 & 36.1 & 66.7 & 10.47 \\
\hline \multirow[t]{2}{*}{ Subtotal } & & 72.9 & 76.1 & 45.9 & 51.9 & 22.7 & 25.4 & \\
\hline & & \multicolumn{2}{|c|}{$\begin{array}{l}x^{2}=1.39 \\
p=0.238\end{array}$} & \multicolumn{2}{|c|}{$\begin{array}{l}x^{2}=3.75 \\
p=0.053\end{array}$} & \multicolumn{2}{|c|}{$\begin{array}{l}x^{2}=1.02 \\
p=0.312\end{array}$} & \\
\hline Total ( 1027 ) & 74.4 & \multicolumn{2}{|c|}{74.4} & \multicolumn{2}{|c|}{48.8} & \multicolumn{2}{|c|}{24.0} & 8.64 \\
\hline
\end{tabular}

$X^{2}$ test for caries prevalence (DMFT $>0$ ) by age-groups ${ }^{*} p<0.05 ; X^{2}$ test for each gender; $\uparrow p<0.10, \ddagger$ non significant, $\uparrow \mathrm{p}<0.001$; DMFT =teeth with caries, missing teeth and filled teeth; $\mathrm{SiC}=$ significant caries index; $M=$ males; $W=$ females. 
Table 3. Logistical regression analysis of caries prevalence $(\mathrm{DMFT}>0)$ by age and gender

\begin{tabular}{llcc}
\hline Age-Gender & COR $(95 \% \mathrm{Cl})$ & AOR $(95 \% \mathrm{Cl})$ & $\begin{array}{c}\mathrm{P} \\
\text { value }\end{array}$ \\
\hline Age \\
$\quad$ Adolescents & $1^{*}$ & & \\
$\quad$ Young adults & $2.10(1.36-3.25)$ & $2.21(1.42-3.44)$ & 0.000 \\
$\begin{array}{l}\text { Sex } \\
\quad \text { Males }\end{array}$ & $1^{*}$ & & \\
$\quad$ Females & $1.18(0.89-1.57)$ & $1.28(0.96-1.71)$ & 0.087 \\
\hline COR = crude odds ratio; AOR = adjusted odds ratio; * reference category
\end{tabular}

\section{DISCUSSION}

Reports about oral health in adolescents and young adults (16 to 25 years old) are rare; this is thus the first study in Mexico which includes a representative sample. A $74.4 \%$ overall caries prevalence was observed in this report and the degree of severity was $48.8 \%$ for $>3$ DMFT and $24.0 \%$ for $>6$ DMFT, whilst the DMFT index was $4.04 \pm 3.9$ for teeth with caries. Comparison with other studies was limited by previous studies not having the same age range and both genders being involved in the present investigation.

Studying Mexican students' dental caries revealed that males in the present sample were less affected (71.7\% prevalence) than conscripts affected by caries in Brazilian studies ( $81 \%$ ), this being $10 \%$ lower than the Brazilian studies $(20,21)$. Another study carried out in Brazil reported a 4.5 DMFT index while the present study gave 3.48 , indicating that the Brazilian subjects had one tooth on average more affected by caries than the Mexicans at the same age. A more unfavourable DMFT index for young Brazilians was reported in another study when comparing the present results with subjects of the same age (Tables I and II). A 5.94, 6.42, 7.13 and 8.86 DMFT index and 90.6\%, 90.5 \%, 94.6\% and $94.9 \%$ dental caries prevalence were reported in 16-, 17-, 18- and 19-year old adolescents, respectively (3). Reports from countries such as Italy have shown dental caries prevalence $(87.8 \%$ ) in 18-year-old adolescents being higher than in the present study. A similar dental caries pattern has been reported in 18- and 19year old Israeli recruits (6.77 DMFT) (17).

By contrast, the present report's results were higher than those observed in male Australian recruits (17- to 20-year-olds) where a 3.59 DMFT was reported. However, a 4.39 DMFT index was obtained for the 21-25-year-old age-group while the Australian researchers observed a 4.63 DMFT index (18). The same authors' results were more encouraging in a more recent study than results from 
the present study; they observed a 2.43 and 3.44 caries index for the same agegroup. They also reported $67.2 \%$ and $73.5 \%$ caries prevalence while in our study the prevalence observed was higher $(73.5 \%)$ for the 17 to 20 age-group and $86.7 \%$ for the 21 to 25 age-group (19). There are reports of lower DMFT index in subjects having ages comparable to those covered by the present report (32).

The highest DMFT index percentage was returned for the "teeth with caries" component in studies performed on 6 to 15 year-old Mexican children and adolescents, in line with results reported from other Latin-American countries $(2,5,33)$. However, the present study's results indicated that the highest caries index percentage was in the "filled teeth" component, indicating that older students had been exposed to a greater amount of restorative treatments; the same observations have been made from Brazil $(3,20,21)$, Israel (17) and Australia $(18,19)$. Nevertheless, it has been reported that the main DMFT index component for 18-year-old boys was "teeth with caries" (34).

In agreement with most studies, it was found that the experience of caries was higher in females than males and dental caries' prevalence and severity was higher as age increased, as in observations made in other Mexican studies (6,8$14,35)$ and in studies performed in other parts of the world. It should be mentioned that no differences were founded regarding prevalence and/or severity.

Dental caries is a multifactor disease involving diet, using topical fluorides, preventative programmes in schools, demographic and economic variables and behavior and attitudes concerning oral health. Amongst the limitations hindering comparing our results was that regarding most studies being performed on male samples, even though the usefulness of this kind of study is that epidemiological monitoring can be done. However, the sample studied may not be completely representative of the age-groups included as it is known that females represent the highest percentage of the Mexican population pyramid, whilst they represented only $48 \%$ in this study. Access to being enrolled in a university is different according to social level; students from lower social levels have less possibility of access to a public university while people from the highest levels study in private universities, leaving us a sample being more representative of the middle social economic level. The results and extrapolating them must therefore be carefully interpreted as they were mainly directed towards specific population groups.

It can be said that the present study's results were unfavorable when compared to reports from first world countries; however, a better oral health profile was 
revealed when compared to other studies from Latin-America. High caries experience, prevalence and severity were observed in this sample of Mexican adolescents. On the other hand, taking DMFT index components into account, restorative experience was high $(59.5 \%)$ when compared to other studies carried out in Mexico and Latin-America

\section{REFERENCES}

1. Archila L, Bartizek RD, Gerlach RW, Jacobs SA, Biesbrock AR. Dental caries in school-age children residing in five Guatemalan communities. J Clin Dent 2003; 14:53-8.

2. Solorzano I, Salas MT, Chavarria P, Beltran-Aguilar E, Horowitz H. Prevalence and severity of dental caries in Costa Rican schoolchildren: results of the 1999 national survey. Int Dent J 2005; 55:24-30.

3. Gushi LL, Soares Mda C, Forni TI, Vieira V, Wada RS, de Sousa Mda L. [Dental caries in 15-to-19year-old adolescents in Sao Paulo State, Brazil, 2002]. Cad Saude Publica 2005; 21:138391.

4. Peres MA, Peres KG, Traebert J, Zabot NE, Lacerda JT. Prevalence and severity of dental caries are associated with the worst socioeconomic conditions: a Brazilian cross-sectional study among 18-year-old males. J Adolesc Health 2005; 37:103-9.

5. Herrera MS, Medina-Solís CE, Maupomé G. Experiencia y prevalencia de caries dental en escolares de León, Nicaragua. Gac Sanit 2005; 19:302-6.

6. Pontigo-Loyola AP, Medina-Solis CE, Borges-Yáñez SA, Patiño-Marín N, Islas-Márquez A, Maupomé G. Prevalence and severity of dental caries in adolescents ages 12 and 15 living in communities with various fluoride concentrations. J Public Health Dent 2007; 67:8-13.

7. Pitts NB, Stamm JW. International Consensus Workshop on Caries Clinical Trials (ICW-CCT) - Final consensus statements: Agreeing where the evidence leads. J Dent Res 2004; 83(Spec Iss C):C125-8.

8. Moreno-Altamirano A, Carreón-García J, Alvear-Galindo G, López-Moreno S, Vega-Franco L. Riesgo de caries en escolares de escuelas oficiales de la Ciudad de México. Rev Mex Pediatr 2001; 68:228-33.

9. Segovia-Villanueva A, Estrella-Rodríguez R, Medina-Solís CE, Maupomé G. Dental caries experience and factors among preschoolers in Southeastern Mexico: A brief communication. J Public Health Dent 2006; 66:88-91.

10. Beltrán-Valladares $P$, Cocom-Tum H, Casanova-Rosado JF, Vallejos-Sánchez AA, Medina-Solís CE, Maupomé G. Caries prevalence and some associated factors in 6-9-year-old schoolchildren in Campeche, Mexico. Rev Bioméd 2006; 17:25-33.

11. Vallejos-Sánchez AA, Medina-Solís CE, Casanova-Rosado JF, Maupomé G, Casanova-Rosado AJ, Minaya-Sánchez M. Defectos del esmalte, caries en dentición primaria, fuentes de fluoruro y su relación con la presencia de caries en dientes permanentes. Gac Sanit 2007; 21:227-34.

12. Irigoyen-Camacho ME. Caries dental en escolares del Distrito Federal. Salud Pública Mex 1997; 39:133-6.

13. Casanova-Rosado AJ, Medina-Solís CE, Casanova-Rosado JF, Vallejos-Sánchez AA, Maupomé G, Ávila-Burgos L. Dental caries and associated factors in Mexican schoolchildren aged 6-13 years. Acta Odontol Scand 2005; 63:245-51.

14. Medina-Solis CE, Maupomé G, Pelcastre-Villafuerte B, Avila-Burgos L, Vallejos-Sánchez AA, Casanova-Rosado AJ. Desigualdades socioeconómicas en salud bucal: caries dental en niños de 6 a 12 años de edad. Rev Invest Clin 2006; 58:296-304. 
15. Kruger E, Thomson WM, Poulton R, Davies S, Brown RH, Silva PA: Dental caries and changes in dental anxiety in late adolescence. Community Dent Oral Epidemiol 1998; 26:355-9.

16. Petti S, Tarsitani G, Panfili P, Simonetti D'Arca A. Oral hygiene, sucrose consumption and dental caries prevalence in adolescent systemic fluoride nonusers. Community Dent Oral Epidemiol 1997; 25:334-6.

17. Levin L, Shenkman A. The relationship between dental caries status and oral health attitudes and behavior in young Israeli adults. J Dent Educ 2004; 68:1185-91.

18. Hopcraft M, Morgan MV. Dental caries experience in a young adult military population. Aust Dent J 2003; 48:125-9.

19. Hopcraft M, Morgan MV. Dental caries experience in Australian army recruits 2002-2003. Aust Dent J 2005; 50:16-20.

20. Gonçalves RE, Peres MA, Marcenes W. Dental caries and socioeconomic conditions: a crosssectional study among 18 years-old male in Florianópolis, Santa Catarina State, Brazil. Cad Saude Publica 2002; 18:699-706.

21. Amaral MA, Nakama L, Conrado CA, Matsuo T. Dental caries in young male adults: prevalence, severity and associated factors. Braz Oral Res 2005; 19:249-55.

22. Orozco-Zurita NE, Jiménez-Férez J, Esquivel-Hernández RI. Estudio de salud bucodental en estudiantes de la carrera de cirujano dentista de la FES Iztacala. Rev ADM 2007; 64:525.

23. Instituto Nacional de Estadística, Geografía e Informática [Internet]. Disponible en: http:// www.inegi.gob.mx/est/contenidos/espanol/sistemas/conteo2005/localidad/iter/ default.asp Consultado Noviembre de 2007.

24. Gobierno de San Luis Potosí [Internet]. Disponible en: http://www.slp.gob.mx/sanluis potosi_infra2.cfm Consultado Noviembre de 2007.

25. Asociación Mexicana de la Industria Salinera A. C. [Internet]. Disponible en: http:// www.amisac.org.mx/page31.html Consultado Noviembre de 2007.

26. Comisión Federal para la protección contra riesgos sanitarios [Internet]. Disponible en: http:// www.cofepris.gob.mx/inf/sal/listado_sal_yodada.htm Consultado Noviembre de 2007.

27. Asociación Médica Mundial [Internet]. Disponible en: http://www.wma.net/s/policy/b3.htm Consultado Noviembre de 2007.

28. WHO. Oral Health Survey-Basics Methods. 4th ed. Geneva: World Health Organization; 1997.

29. Brathall D. Introducing the Significant Caries Index together with a proposal for a new global oral health goal for 12-year-olds. Int Dent J 2000; 50:378-84.

30. Walsh J. International patterns of oral health care - the example of New Zealand. NZ Dental J 1970; 66:143-52.

31. Jong A. Dental public health community dentistry. St. Louis: Mosby Co. 1981; 74-88.

32. Senna A, Campus G, Gagliani M, Strohmenger L. Socio-economic influence on caries experience and CPITN values among a group of Italian call-up soldiers and cadets. Oral Health Prev Dent 2005; 3:39-46.

33. Rihs LB, Sousa Mda L, Cypriano S, Abdalla NM, Guidini DD, Amgarten C. Dental caries activity in primary dentition, Indaiatuba, Sao Paulo, Brazil, 2004 Cad Saude Publica 2007; 23:593600

34. Bastos JLD, Nomura LH, Peres MA. [Dental pain, socioeconomic status, and dental caries in young male adults from southern Brazil] Cad Saúde Pública 2005; 21:1416-23.

35. Villalobos-Rodelo JJ, Medina-Solís CE, Maupomé G, Pontigo-Loyola AP, Lau-Rojo L, VerdugoBarraza L. Caries dental en escolares de una comunidad del Noroeste de México con dentición mixta, y su asociación con algunas variables clínicas, socioeconómicas y sociodemográficas. Rev Invest Clin 2007; 59:256-267. 